\title{
Redaksjonelt
}

\section{Nye artikler}

På tampen av 2008 har Acta Didactica Norge publisert tre nye artikler og en bokomtale.

I artikkelen "Intercultural competence - an aim for the teaching of English in Norway?” utforsker Ragnhild Elisabeth Lund hvordan interkulturell kompetanse blir fulgt opp i Kunnskapsløftet 2006. Hun drøfter hvordan denne kompetansen kan utvikles gjennom engelskundervisningen, blant annet ved å vise til prosjekt i regi av Europarådet. Hovedfokus i artikkelen er utvalg av interkulturelle emner og vurdering av interkulturell kompetanse. Hovedutfordringen, skriver Lund, er å sikre at det i det hele tatt arbeides med interkulturelle spørsmål i klasserommet.

Gunn Elin Heimark skriver i artikkelen "Praktisk tilnærming i praksis” om en kasusundersøkelse med fokus på seks fransklæreres forståelse av praktisk tilnærming i fremmedspråkundervisningen. Hun konkluderer med at de fleste lærerne ennå ikke helt har inkludert læreplanens hovedområde "Språklæring” i den praktiske tilnærmingen. Det synes ikke å være noe skarpt skille mellom den praktiske tilnærmingen som ligger til grunn for Lcereplan $i$ fremmedspråk, LK06, og hvordan man på ungdomstrinnet underviste i tilvalgsspråkene tysk og fransk etter L97. Utfordringen blir å tilrettelegge undervisningen og den praktiske tilnærmingen slik at den i større grad bidrar til at elevene får innsikt i egen språklæring, til økt bruk av digitale verktøy, og til økt bruk av målspråket i klasserommet, understreker Heimark.

I artikkelen "Konfliktperspektiver i religionsundervisning og religionsdidaktikk - en bredere og bedre tilnærming til religion?" legger Bengt Ove Andreassen til grunn en forståelse av religion som til en viss grad skiller seg fra etablerte perspektiver i norsk religionsdidaktikk. Han drøfter ulike aspekter ved introduksjon av konfliktperspektiver i religionsundervisningen. En slik tilnærming er faglig utfordrende, men gir innblikk i en side ved religion som har vært lite utforsket i norsk religionsdidaktisk sammenheng. Norske religionsdidaktikere har i all hovedsak heller hentet perspektiver fra økumenikk og religionsdialog enn å utforske konflikter der religion inngår, for å lære noe om religioner, skriver han.

Knut Steinar Engelsen omtaler boka Undervisning i endring - IKT, aktivitet, design (2007) av Trond Eiliv Hauge, Andreas Lund og Jon Magne Vestøl. Han påpeker at forfatterne lykkes i å vise hvordan samfunnsutviklingen, særlig innføring av ny informasjonsteknologi, fører til at tradisjonelle oppfatninger om læring og undervisning settes under press, og at lærerens rolle i den nye tida er enda viktigere enn før. Han mener at boka kan bidra til en aktiv dialog mellom forskningsmiljøene og praksisfeltet. 
I 2008 har ADNO i alt publisert 8 artikler og to bokomtaler. Blant artiklene finner vi én som handler om didaktikk generelt, to om religionsdidaktikk, én om norskdidaktikk, tre om engelskdidaktikk og én om fremmedspråkdidaktikk. Dette er ikke et resultat av en redaksjonell planlegging, men et uttrykk for hva slags manus som har kommet inn til tidsskriftet, og som har blitt akseptert etter å ha vært gjennom den faglige og redaksjonelle prosessen. Det kan også være en konsekvens av få alternative tellende publiseringskanaler.

Det tar tid å utvikle tidsskriftet slik at det fanger opp bredden i den fagdidaktiske forskningen i Norge. Ved inngangen til 2009 har ADNO en rekke manus til vurdering og redigering. Disse spenner over et stort fagdidaktisk spekter. Med kort publiseringstid kan ADNO raskt formidle fersk forskning, og vi ser fram mot å publisere fagdidaktiske forskningsnyheter i 2009.

Oslo, februar 2009

Rita Hvistendahl

Ansvarlig redaktør 